\title{
The effectiveness of management accounting systems in SMEs: A multidimensional measurement approach
}

\section{Elsa Pedroso}

Assistant Professor, University of Coimbra, Centre for Business and Economics Research (CeBER), Faculty of Economics.

Email: elsa.pedroso@fe.uc.pt

\section{Carlos F. Gomes}

Associate Professor, University of Coimbra, Centre for Business and Economics Research (CeBER), Faculty of Economics.

Email: cfgomes@fe.uc.pt

This is a pre-copyedited version of an article published in the Journal of Applied Accounting Research. The final version of this article is available online at

This manuscript version is made available under the Creative Commons Attribution Noncommercial International Licence 4.0 (CC BY-NC 4.0). Reuse is allowed in accordance with the terms outlined by this license.

Citation: Pedroso, Elsa and Gomes, Carlos F. (2020), "Measuring the effectiveness of management information systems: A multidimensional approach for small and medium enterprises", Journal of Applied Accounting Research, https://doi.org/10.1108/JAAR-05-2018-0059. 


\section{The effectiveness of management accounting systems in SMEs: A multidimensional measurement approach}

\section{Structured abstract}

Purpose - The purpose of this paper is to present and validate a multidimensional approach to measure the effectiveness of management accounting systems.

Design/methodology/approach - Based on an extensive literature review, the most appropriate information dimensions were identified. To validate the multidimensional tool, survey data were obtained from 284 chief financial officers of Portuguese small and mediumsized enterprises. A structural equation model, evaluating the influence on the managerial performance, was used to verify the nomological validity of this new construct.

Findings - The results of this study suggest that the effectiveness of management accounting systems can be measured using a second-order construct. This construct includes 14-items, covering four dimensions of the management information characteristics.

Research limitations/implications - Although contributing to the advancement of knowledge, it is, however, limited to the Portuguese organizational environment and culture. Therefore, further studies should be carried out in other organizational contexts and cultures, to test and validate this multidimensional tool.

Practical implications - The multidimensional tool presented and validated in this study can be used by executives of SMEs for assessing the effectiveness of their management accounting systems, which can help to improve SMEs' performance measurement and benchmarking processes.

Originality/value - On the best of our knowledge, this is the first study wherein the MAS is modeled as a second-order construct from the perspective of multidimensional information characteristics. This second-order approach recognizes the contribution and retains the distinctive nature of each first-order construct, representing the management accounting system. This multidimensional construct could be very important for future research by allowing to capture synergies resulting from the balanced development of its four information dimensions, and consequently, offer new contributions to management accounting knowledge.

Paper type - Research paper

Keywords - Management accounting systems, Management information systems, Performance management, Information characteristics, Effectiveness, Small and mediumsized enterprises, SME. 


\section{The effectiveness of management accounting systems in SMEs: A multidimensional measurement approach}

\section{Introduction}

The current competitive environment has forced small and medium-sized enterprises (SMEs) to change and adapt to meet new challenges continuously. These challenges have contributed to increasing the importance of information quality in the decision-making process. In this context, management accounting systems (MAS) become a powerful decision support tool to assist business processes management (Faherty and Stephens, 2016; Soobaroyen and Poorundersing, 2008). The information provided by these systems has also become an essential management tool that can contribute to increasing the competitiveness of SMEs in the global marketplace.

Research relating management accounting (MA) has been quite considerable and cuts across different industries and different countries (Ahmad and Zabri, 2015). Traditionally, this research stream has associated MA with large, established companies, questioning its usefulness for small and medium enterprises (Bisbe and Malagueño, 2009). One of the arguments against the use of MA in SMEs is that it would encourage a command and control mechanism that can eliminate innovation (Davila et al., 2009), which is one of the strongest competitive resources of these companies. However, this traditional view where management accounting is unsuitable for innovation has been challenged (Chenhall and Moers, 2015), leading to a paradigm shift in the use of MAS by the executives of small and medium enterprises (Davila et al., 2009) being able to assist them in the continuous process of change (Aaltola, 2019). As such, MA approaches in SMEs should be differentiated from those for large companies, taking into account their innovative and organizational characteristics (Pelz, 2019)

We can find several research topics on management accounting, which deepened our understanding of how enterprises can use this management tool to improve their performance and therefore improve their competitiveness. Sometimes the literature uses the terms management accounting (MA), management accounting systems (MAS), management control systems (MCS), and organizational controls (OC) interchangeably (Chenhall, 2003). This blurring seems to exist because of the difficulty in distinguishing between control systems 
and decision support systems (Zimmerman, 2001). Given the organizational characteristics of SMEs and their difficulties in competing in the global marketplace, it seems more appropriate to use the management accounting system as a decision support system. As such, it should be designed to support decision-making at any organizational level (Malmi and Brown, 2008).

In this context, the management accounting systems and the information they provide are topics that have gained increasing research relevance. As such, recent literature has been calling for more research on this subject for SMEs (Azudin and Mansor, 2018; Ismail et al., 2019; Lavia López and Hiebl, 2015; Pelz, 2019; Sandalgaard and Nielsen, 2018).

Based on the literature reviewed, different approaches to measuring the effectiveness of management accounting systems were found (Chong, 2004; Etemadi et al., 2009; Gunarathne and Lee, 2019; Heidmann et al., 2008; Ivankovič et al., 2010; Mia and Patiar, 2001; Novas et al., 2017; Sharma et al., 2006). However, these different approaches have prevented the comparability of research results, which can hinder the advancement of knowledge on this important subject. They can also reduce the practical contributions for enterprises, by decreasing their benchmarking capability, and thus make it harder to increase their competitiveness.

To fill this gap in management accounting literature, we need a clearer understanding of the definition of management accounting systems (MAS) and their informational dimensions, along with a new operational approach to measure their effectiveness. As such, an additional research effort is needed to understand the implications of MAS being integrated into a network of strategic organizational resources in response to the external competitive environment.

In this context, the objective of this study is to present and validate a multidimensional approach to measure the effectiveness of management accounting systems.

The main results of this study suggest that the effectiveness of management accounting systems can be measured using a second-order construct, covering four dimensions of management information characteristics, recognizing MAS overall contribution, and maintaining the distinct nature of each first-order construct. This new multidimensional approach can be very important for future research, allowing to capture synergies resulting 
from the balanced development of its four dimensions of information and, consequently, offer new contributions to the knowledge of management accounting.

This new approach will also provide useful managerial implications to SMEs operating in competitive markets. They will benefit from a clear vision of how they can take advantage of MAS opportunities embedded in direct and indirect resource relationships. It will also be an important contribution to the benchmarking process in SMEs and the consequent increase in their competitiveness in the global market.

This paper consists of five sections. In the next section, a background of management accounting systems is provided, based on the literature reviewed for the last fifteen years. Section three describes the research methodology, including the research instrument, sample characteristics, and data collection. Section four presents and discusses the research results. Section five presents the conclusions of this study, including the contributions to literature, implications for enterprises, limitations of the study, and suggestions for future research.

\section{Background}

The implementation and use of management accounting, like other business management practices, have benefited from the latest developments in information technology. As such, the implementation and utilization of management accounting practices are usually supported by the management accounting systems.

Several directions have been followed to evaluate the effectiveness of management accounting and its interaction with other variables in the business environment. Based on the literature reviewed, the following approaches to the study of management accounting interaction with the organizational environment were identified:

- management accounting information (Choe, 2004; Cleary, 2009);

- the characteristics of the information provided by the management accounting systems (Bouwens and Abernethy, 2000; Ern et al., 2016; Ismail et al., 2018; Ramli and Iskandar, 2014); 
- the structure of management accounting systems (Cohen and Kaimenaki, 2011; Macinati and Anessi-Pessina, 2014);

- changes in accounting and management control systems (Hoque, 2011; Williams and Seaman, 2002);

- management accounting practices used by organizations (Ahmad and Zabri, 2015; Angelakis et al., 2010; Pavlatos and Paggios, 2009);

- the use of strategic management accounting (Cadez and Guilding, 2008; Cinquini and Tenucci, 2010).

In this context, the information characteristics of the management accounting system (MAS) was found to be the topic of more relevance in the literature, as MAS is a fundamental source of information for supporting decision-making.

The literature reviewed shows that management accounting systems interact with a wide variety of organizational and environmental variables. Some of these variables are: top management support (Fong and Quaddus, 2010), task uncertainty (Soobaroyen and Poorundersing, 2008), organizational interdependence (Chenhall and Morris, 1986), users satisfaction (Fong and Quaddus, 2010), perceived environmental uncertainty (Chenhall and Morris, 1986; Hammad et al., 2013), decentralization (Chenhall and Morris, 1986; Ern et al., 2016; Hammad et al., 2013; Soobaroyen and Poorundersing, 2008), managerial performance (Soobaroyen and Poorundersing, 2008; Etemadi et al., 2009; Hammad et al., 2013), and organizational performance (Harrison, 2009; Ismail et al., 2018). Both the influence of these factors on the MAS effectiveness and the influence of MAS on performance have been investigated. However, different conclusions were reached across these studies.

The most cited operationalization of the management accounting system concept was introduced by Chenhall and Morris (1986). They defined MAS regarding four information characteristics, namely, scope, timeliness, level of aggregation, and level of integration.

Since then, several authors have used the constructs representing these informational dimensions. However, in the last fifteen years, only a few authors choose to measure MAS using all these four dimensions individually (Table 1). 
Some authors only used the constructs representing the scope and timeliness dimensions (Etemadi et al., 2009; Heidmann et al., 2008), while others decided to evaluate only the scope dimension (Naranjo-Gil and Hartmann, 2007; Pondeville et al., 2013; Sharma et al., 2006).

Along with the differences in the number of the constructs used, other differences were found relating to how these constructs were used. Some were used to assess the availability of the information (Chenhall and Morris, 1986; Etemadi et al., 2009; Soobaroyen and Poorundersing, 2008), while others were used to assess the extent to which the information was utilized (Chong, 2004; Agbejule, 2005; Sharma et al., 2006; Fong and Quaddus, 2010; Hammad et al., 2013). Differences in the constructs' structure were also found. Although Chenhall and Morris (1986) used four items to measure timeliness, some authors used two items (Abdel-Kader and Luther, 2006; Choe, 2002), while other authors used only one item (Mia and Patiar, 2001; Ivankovič et al., 2010).

Given the differences in utilization of the constructs described by Chenhall and Morris (1986), and used by many other authors, it seems to be difficult to compare the research results obtained by them. Moreover, these studies do not investigate management accounting systems as a comprehensive concept: they examine their components using several empirical approaches. As such, it becomes tough to compare the theoretical and practical implications of these studies.

Therefore, it seems very important, for academics and executives of small and medium-sized enterprises, to operationalize a construct that can conceptually represent management accounting systems as a comprehensive multidimensional concept. This new approach can also be helpful for developing management accounting theories (Malmi and Granlund, 2009).

\section{Methodology}

\subsection{Research instrument}

The research instrument used in this study was designed based on an extensive literature review, which leads us to choose four informational dimensions to measure the management accounting systems effectiveness, developed by Chenhall and Morris (1986) and further used 
by several others authors (e.g., Ghasemi et al., 2016; Gunarathne and Lee, 2019; Ismail et al., 2018). For measuring the managerial performance, we used a construct developed by Mahoney et al. (1963) and further used by Hall (2008) and Hammad et al. (2013). This construct evaluates managers in the performance of their daily tasks and activities of planning, investigating, coordinating, evaluating, supervising, staffing, negotiating, and representing. It also evaluates managers' overall performance.

In the first phase of developing the questionnaire, it was translated and adapted to the Portuguese business environment. In the second phase, the instrument was submitted to a panel of experts from several organizations to fit the SMEs' environment. During this phase, particular attention was given to the use of terminology consistent with the background of the survey participants.

The final version of the research instrument contains nineteen items representing the observed characteristics of the information provided by the management accounting systems. For these information characteristics (see Appendix A), the respondents were asked to rate the extent they use them, ranging from 1 (never) to 7 (always). The research instrument also includes nine items representing the dimensions of managerial performance along with the overall performance. For these items (see Appendix B), the respondents were asked to rate their performance in executing their daily tasks and activities, ranging from 1 (unacceptable) to 7 (excellent). It also was possible to choose "not applicable" if they did not execute any of those tasks or activities.

The research instrument also includes questions on the characteristics of the enterprises, including turnover, assets, the number of employees, and industry type.

\subsection{Sample}

For this study, the data was collected through an online survey questionnaire. Chief Financial Officers (CFOs) of Portuguese small and medium-sized enterprises (SMEs) were invited to participate in the study. 
The names and addresses of 1500 SMEs were obtained from Informa DB, which belongs to the Dun \& Bradstreet Worldwide Network. All these enterprises were contacted by phone to explain the objective of the research study and to obtain the name of their CFO. Twelve of them, despite several attempts, never answered the phone. Ninety-three enterprises declined to collaborate in this research study for several reasons, such as no longer operating, and lack of autonomy to answer this kind of questionnaire. After these contacts, an email explaining the purpose of the research and containing the link to the online survey was sent to 1407 CFOs of Portuguese SMEs. A reminder email was sent every two weeks over the next five months. As an incentive to increase the respondent's participation, they were promised a summary of the research findings. A total of 284 usable responses were obtained from CFOs, which was a response rate of 20.23 percent. This response rate cannot be considered high. However, it is consistent with similar reported studies (Hall, 2008; Moores and Yuen, 2001). Table 2 presents the sample characteristics.

\section{[Insert Table 2]}

\section{Results and discussion}

\subsection{A comprehensive multidimensional approach of MAS}

\subsubsection{Data analysis}

The data obtained were analyzed using exploratory factor analysis (EFA) and confirmatory factor analysis (CFA) with the maximum likelihood estimation (MLE) method. IBM SPSS and IBM AMOS (version 22) were used.

The univariate normality was confirmed by skewness and kurtosis values (Appendix A). Although the Mardia coefficient (146.1) was above the suggested threshold, the maximum likelihood estimation method is robust against multivariate non-normality data (Hoyle, 1995; Kline, 2011; Tabachnick and Fidell, 2007).

Outlier analysis was performed using the Mahalanobis squared distance. This analysis did not lead to any outlier identification. Therefore, no observation was dropped. 


\subsubsection{The multidimensional components of MAS}

The psychometric properties of the instrument were checked for unidimensionality, internal consistency, convergent, and discriminant validity of each construct. To test unidimensionality, exploratory factor analysis was executed for each construct, using principal components analysis and the varimax rotation method. As Table 3 shows, all the construct data has a good level of adequacy, with KMO values above 0.745 and significance level $<0.00$ for Bartlett's test of sphericity.

\section{[Insert Table 3]}

Cronbach's alpha values above 0.878 and item-to-total correlation values above 0.659 indicate internal consistency and construct reliability (Hair et al., 2014).

Confirmatory factor analysis was used to check convergent and discriminant validity. All regression weights are statistically significant ( $p$-value $<0.001)$ and their standardized estimates are greater than 0.5 . However, the first model revealed an insufficient fit $\left(\chi^{2} / d f=\right.$ 5.317; $\mathrm{CFI}=0.851 ; \mathrm{TLI}=0.825 ; \mathrm{RMSEA}=0.124 ; \mathrm{PCFI}=0.726)$.

Modification indices and standardized residuals analysis provided some re-specification suggestions to improve the model fit. To avoid correlating error terms (Anderson and Gerbing, 1988; Hair et al., 2014), items SCO04, SCO05, TIM02, AGG05, and AGG07 were dropped during the re-specification process.

After the above changes, the fit of the model was improved $\left(\chi^{2} / d f=3.555 ; C F I=0.937 ; T L I=\right.$ 0.919; RMSEA = 0.095; PCFI = 0.731). All regression weights are statistically significant ( $p$-value $<0.001)$ and their standardized estimates are greater than 0.5 , which indicates internal consistency of the model (Anderson and Gerbing, 1988; Hair et al., 2014).

Convergent validity and reliability were assessed using composite reliability (CR) and average variance extracted (AVE) indicators (Fornell and Larcker, 1981) and Cronbach alpha (Cronbach, 1951). According to the results (Table 4), all CR values are higher than 0.846 , which indicates internal consistency. All the AVE values are higher than 0.593, which suggests suitable 
convergent validity (Hair et al., 2014). Cronbach's alpha also indicates construct reliability with values greater than 0.839 .

\section{[Insert Table 4]}

Construct validity also implies that the constructs are distinct from each other. There is discriminant validity if the AVE for any two constructs is greater than the square of the correlation estimates between these two constructs (Fornell and Larcker, 1981). The results in Table 4 show small differences between values for integration, timeliness, and aggregation, which could indicate a lack of discriminant validity between these constructs. However, these results may also indicate the need for a second-order construct (Bollen, 1989). The high correlations between constructs also could suggest the need for a second-order construct, including the four validated first-order constructs, which supports the objective of our study.

\subsubsection{A comprehensive approach to measuring MAS}

Although a second-order factor has not been mentioned yet in the literature review, these four previously mentioned dimensions have been used individually by several authors.

According to literature, there are constructs whose conceptualization is best represented by higher orders of abstraction. In these cases, a higher-order modeling approach would be the most appropriate technique to represent such structures (Koufteros et al., 2009). Therefore, based on the results, it seems justifiable to suggest MAS as a second-order factor, formed by the four first-order constructs representing the informational dimensions Scope, Timeliness, Aggregation, and Integration.

The second-order factor model revealed a similar model fit compared with the first-order model, having the following goodness-of-fit indices: $\chi^{2} / d f=3.507 ; \mathrm{CFI}=0.936 ; \mathrm{TLI}=0.921$; RMSEA $=0.094 ; \mathrm{PCFI}=0.751$. All regression weights are statistically significant $(p$-value $<$ 0.001) and their standardized estimates are greater than 0.5 (Anderson and Gerbing, 1988; Hair et al., 2014), as shown in Figure 1.

The modified expected cross-validation index for maximum likelihood estimation was smaller on the second-order factor model than in the first-order model (1.146 in the first-order model 
and 1.143 in the second-order factor model), indicating the second-order factor model has better external validity than the first-order factor model.

\section{[Insert Figure 1]}

The second-order factor model presents CR and AVE values that suggest internal consistency and convergent validity (Table 5). The AVE of the second-order construct (71.2\%) indicates that the shared variance of the first-order constructs allows the validation of this second-order construct. Thus, there is empirical evidence to support the existence of a MAS multidimensional second-order construct.

\section{[Insert Table 5]}

\subsection{The nomological validation of the second-order construct representing MAS}

\subsubsection{The measurement model}

After the internal validation of the second-order construct representing the multidimensional approach for measuring the management accounting system, the managerial performance (MP) construct was used to validate nomologically the MAS.

The unidimensionality of the MP was checked through exploratory factor analysis. Table 6 shows that the construct data has a good level of adequacy, with a KMO value of 0.931 and a significance level $<0.00$ for Bartlett's test of sphericity.

\section{[Insert Table 6]}

A Cronbach's alpha value of 0.923 and item-to-total correlation values above 0.630 indicate internal consistency and construct reliability (Hair et al., 2014).

Confirmatory factor analysis was used to check convergent and discriminant validity. Modification indices suggested correlations between the M_P07 and M_P08 error terms. To avoid correlating error terms, item M_P07 was dropped.

Once re-specified with the above change, the fit of the final model was considered acceptable $\left(\chi^{2} / d f=2.216 ; C F I=0.933 ; \mathrm{TLI}=0.924 ; \mathrm{RMSEA}=0.069 ; \mathrm{PCFI}=0.824\right)$. All regression weights 
are statistically significant ( $p$-value $<0.001)$, and their standardized estimates are greater than 0.5 (Table 7), which indicates the internal consistency of the model (Anderson and Gerbing, 1988; Hair et al., 2014).

\section{[Insert Table 7]}

According to the results (Table 7 ), all CR values are greater than 0.833 , which indicates internal consistency. All the AVE values are higher than 0.542 , which suggests suitable convergent validity (Hair et al., 2014). Cronbach's alpha also indicates construct reliability, with values greater than 0.825 . Comparing the AVE values with the square of the correlation between managerial performance and MAS constructs $(0.274)$ indicates their discriminant validity.

After validating the measurement model, we estimated the structural model to test the influence of MAS on managerial performance.

\subsubsection{The structural model}

The structural model revealed the same goodness-of-fit indices as the measurement model $\left(\chi^{2} / \mathrm{df}=2.216 ; \mathrm{CFI}=0.933 ; \mathrm{TLI}=0.924 ; \mathrm{RMSEA}=0.069 ; \mathrm{PCFI}=0.824\right)$, indicating that this is an acceptable model. All regression weights are statistically significant ( $p$-value $<0.001)$ and their standardized estimates are greater than 0.5 (Anderson and Gerbing, 1988; Hair et al., 2014).

Based on the results (Figure 2), we verify that Management Accounting Systems have a positive influence on managerial performance, which allows their nomological validation.

Overall, the results show that using MAS as a second-order construct is not only conceptually justified but also empirically supported.

\section{[Insert Figure 2]}

\subsection{Discussion}

The objective of this study is to present and validate a multidimensional approach to measure the effectiveness of management accounting systems (MAS). To achieve this objective, this study used and extended the theoretical work of Chenhall \& Morris (1986) which has been widely used by the management accounting literature (e.g., Agbejule, 2005; Ern et al., 2016; 
Gunarathne \& Lee, 2019; Hammad et al., 2013; K. Ismail et al., 2018). However, these MAS dimensions have been only studied separately and do not allow comparability of results regarding the impact of MAS on business management.

The results of this study confirm the four dimensions of MAS and also show that these dimensions are distinct and interrelated. The results also show the relative importance of the first-order constructs, along with the SMEs executives concerns relating the information provided by the management accounting systems. In this context, the aggregation dimension seems to be the one that most influences the effectiveness of the management accounting system. This result shows that SMEs executives prefer organized information in a way that reflects the activities carried out in the different functional areas and their visibility in the reports that support the strategic decisions. It also shows a strong concern that the information provided by MAS reflects the impact of key market events on the various functional areas. These concerns and information needs stem from the volatility of the market in which SMEs are positioned. In a context of high market volatility, information has become a resource that can provide competitiveness. Therefore, these information characteristics of MAS can add competitiveness to SMEs. To be noted, that SMEs executives do not seem to value costs information separated into fixed and variable components. Perhaps because efficiency is no longer the stronger competitive weapon or because executives have taken for granted this information. In other words, maybe they look at this information as a qualifier. This result is interesting because it may show an evolution of management practices of SME executives, which could confirm the paradigm shift suggested by the literature (Davila et al., 2009). On the one hand, it contradicts some of the literature results (Hammad et al., 2013). On the other hand, it confirms more recent literature regarding the use of this MAS dimension (Ismail et al., 2018).

The integration dimension seems to be the second most influential dimension in MAS. SMEs executives are interested in obtaining information that can reflect not only the impact of their decisions but also the impact of the decisions of other functional managers in their department. They are also interested in the activities of all functional areas having precise goals. This information has become increasingly important in a highly competitive global market where SMEs compete with large companies, requiring information-driven decision 
support tools that can reflect their companies' multidimensional performance. This result seems to contradict the literature on the use of this dimension in large organizations. (Ghasemi et al., 2016; Hammad et al., 2013). However, it is aligned with the importance that SMEs executives attach to the availability of integrated management accounting information (Soobaroyen and Poorundersing, 2008).

The timeliness dimension was found to be in third place. This dimension reflects the concern of executives to obtain information frequently and without delays. This characteristic is one of the most important features for information to be used to support decision-making. In this context, the need for information technologies that can automate information collection, processing, and provision processes is often mentioned. However, more important than information technology is the existence of a culture of effectiveness in which everyone in the organization feels that information is used to support decision-making and will help the company increase its competitiveness. This result seems to confirm that this MAS dimension will be important both for large organizations (Hammad et al., 2013; Naranjo-Gil, 2009) as well as for SMEs (Soobaroyen and Poorundersing, 2008; Velez et al., 2015).

The scope dimension seems to be the one that least influences the effectiveness of the management accounting system. This dimension reflects the need to obtain external information as well as the predictive characteristics of this information. The smaller influence of this dimension may be related to the difficulty of obtaining information with these characteristics. In this context, SME executives may have incorporated this difficulty in their response to the questionnaires on which the empirical study was based. This is the most studied dimension in the literature. Sometimes it was used alone to represent the MAS (Chong, 2004; Naranjo-Gil and Hartmann, 2007; Sharma et al., 2006) and other times used with other dimensions, representing MAS (Ghasemi et al., 2016; Ismail et al., 2018; NaranjoGil and Hartmann, 2007; Soobaroyen and Poorundersing, 2008; Velez et al., 2015). In all cases, the positive relationship with the performance was evidenced, which is also confirmed by this study. 


\section{Conclusions}

Small and medium-sized enterprises are an important lever of each country's economies. Their competitive strength, which lies in their capacity for innovation, has made them important players in the global market, where they fight against large companies. In this context of competition, SMEs have to adapt the decision support tools used by large companies to their organizational realities. Thus, in recent years, we have seen a paradigm shift towards the use of MAS by SMEs. What appeared to be a rigid decision support tool that could eliminate innovation has been turned into a resource that provides competitiveness to these companies (Chenhall and Moers, 2015; Davila et al., 2009) and can even help them to support their effective strategic change initiatives (Aaltola, 2019). Despite the importance and the high number of these companies, which reach $95 \%$ in the European Union, there are still few authors who have studied management accounting systems in SMEs (Ismail et al., 2019). With this study, we intend to contribute to closing this gap.

Based on an extensive and comprehensive literature review covering the past fifteen years, we found that MAS has been measured through various individual constructs. However, we did not find any operationalization of this concept that represents a comprehensive and integrated approach. This means that researchers have investigated the role of each of the MAS dimensions and their impact on business management, but they have not investigated the MAS as a resource that, in addition to its separate dimensions, also represents the interrelationship between them.

To fill this gap in the management accounting literature, we presented and validated a multidimensional approach to measuring the effectiveness of management accounting systems. This approach was operationalized through a second-order construct, which includes four first-order constructs representing the information dimensions most used and cited in the literature reviewed.

Through a systematic process of validation, the four constructs were considered appropriate to the sample used, which represents Portuguese SMEs. The high correlation between the four first-order constructs and their more comprehensive representation of the MAS concept, justified by the literature reviewed, confirms that the objective of this study was fulfilled. 
Based on the results of this study, some important considerations can be presented. First, to the best of our knowledge, this study is the first to develop and validate a second-order construct to measure the effectiveness of management accounting systems. The existence of this second-order construct recognizes the contribution and retains the distinctive nature of each first-order construct, namely scope, timeliness, aggregation, and integration of MAS information. As such, it treats these constructs as facets of the management accounting systems. This multidimensional construct could be very important for future research by allowing the study of new hypotheses and consequently offering new contributions to management accounting knowledge.

Second, the existence of a second-order construct suggests not only that the MAS is a multidimensional concept, but also that there may be synergies resulting from the balanced development of its four information dimensions.

Third, this multidimensional tool could be helpful for study the benefits of the MAS utilization in small and medium-sized enterprises, and for developing new management accounting theories, responding to the recent calls for additional research on these subjects (Azudin and Mansor, 2018; Ismail et al., 2019; Lavia López and Hiebl, 2015; Pelz, 2019; Sandalgaard and Nielsen, 2018).

Fourth, this study contributes to the advancement of knowledge by offering researchers a new tool to measure MAS effectiveness and its influence on performance.

This study also brings practical contributions. The multidimensional tool presented and validated in this study can be used by executives of SMEs for assessing the effectiveness of their management accounting systems. This tool allows executives to adapt MAS to the specific characteristics of their SMEs (Aaltola, 2019), and to evaluate the effectiveness of its utilization.

As such, managers can aggregate their evaluation of the four facets to form their perception of the second-order overall construct, which can help to improve SMEs' performance measurement and benchmarking processes. However, managers should also be concerned with factors that may influence the implementation and effectiveness of MAS utilization, 
including information technologies (Ghasemi et al., 2019) and other contingency factors (Ern et al., 2016; Ramli and Iskandar, 2014).

Although contributing to the advancement of knowledge, it is, however, limited to the Portuguese organizational environment and culture. Therefore, further studies should be carried out in other organizational contexts and cultures, to test and validate this multidimensional tool.

Future research should be conducted to examine the relationship between MAS and managerial performance, as well as their impact on organizational performance. The influence of some important organizational and environmental variables on the MAS should also be examined.

\section{References}

Aaltola, P. (2019), "Strategic thinking and accounting: potentials and pitfalls from a managerial perspective", Journal of Management Control, Springer Berlin Heidelberg, pp. 1-29.

Abdel-Kader, M. and Luther, R. (2006), "Management accounting practices in the UK food and drinks industry", British Food Journal, Vol. 108 No. 5, pp. 336-357.

Agbejule, A. (2005), "The relationship between management accounting systems and perceived environmental uncertainty on managerial performance: a research note", Accounting and Business Research, Vol. 35 No. 4, pp. 295-305.

Ahmad, K. and Zabri, S.M. (2015), "Factors explaining the use of management accounting practices in Malaysian medium-sized firms", Journal of Small Business and Enterprise Development, Vol. 22 No. 4, pp. 762-781.

Anderson, J.C. and Gerbing, D.W. (1988), "Structural equation modeling in practice: A review and recommended two-step approach", Psychological Bulletin, Vol. 103 No. 3, pp. 411423.

Angelakis, G., Theriou, N. and Floropoulos, I. (2010), "Adoption and benefits of management accounting practices: Evidence from Greece and Finland", Advances in Accounting, 
Elsevier Ltd, Vol. 26 No. 1, pp. 87-96.

Azudin, A. and Mansor, N. (2018), "Management accounting practices of SMEs: The impact of organizational DNA, business potential and operational technology", Asia Pacific Management Review, Vol. 23 No. 3, pp. 222-226.

Bisbe, J. and Malagueño, R. (2009), "The choice of interactive control systems under different innovation management modes", European Accounting Review, Vol. 18 No. 2, pp. 371405.

Bollen, K.A. (1989), Structural equations with latent variables, Wiley, New York.

Bouwens, J. and Abernethy, M.A. (2000), "The consequences of customization on management accounting system design", Accounting, Organizations and Society, Vol. 25 No. 3, pp. 221-241.

Cadez, S. and Guilding, C. (2008), "An exploratory investigation of an integrated contingency model of strategic management accounting", Accounting, Organizations and Society, Elsevier Ltd, Vol. 33 No. 7-8, pp. 836-863.

Chang, R.D., Chang, Y.W. and Paper, D. (2003), "The effect of task uncertainty, decentralization and AIS characteristics on the performance of AIS: an empirical case in Taiwan", Information and Management, Vol. 40 No. 7, pp. 691-703.

Chenhall, R.H. (2003), “Management control systems design within its organizational context: findings from contingency-based research and directions for the future", Accounting, Organizations and Society, Vol. 28 No. 2-3, pp. 127-168.

Chenhall, R.H. and Moers, F. (2015), "The role of innovation in the evolution of management accounting and its integration into management control", Accounting, Organizations and Society, Vol. 47 No. November, pp. 1-13.

Chenhall, R.H. and Morris, D. (1986), "The Impact of Structure, Environment, and Interdependence on the Perceived Usefulness of Management Accounting Systems", The Accounting Review, Vol. 61 No. 1, pp. 16-35.

Chiou, B. (2011), "Which types of management accounting system information can be used to respond adequately to environmental uncertainty? The effects of user participation and 
tolerance of ambiguity", African Journal of Business Management, Vol. 5 No. 34, pp. $13293-13301$.

Choe, J. (2002), "The organisational learning effects of management accounting information under advanced manufacturing technology", European Journal of Information Systems, Vol. 11 No. 2, pp. 142-158.

Choe, J. (2004), "The relationships among management accounting information, organizational learning and production performance", The Journal of Strategic Information Systems, Vol. 13 No. 1, pp. 61-85.

Chong, V.K. (2004), "Job-Relevant Information and its Role with Task Uncertainty and Management Accounting Systems on Managerial Performance", Pacific Accounting Review, Vol. 16 No. 2, pp. 1-22.

Cinquini, L. and Tenucci, A. (2010), "Strategic management accounting and business strategy: a loose coupling?", Journal of Accounting \& Organizational Change, Vol. 6 No. 2, pp. 228259.

Cleary, P. (2009), "Exploring the relationship between management accounting and structural capital in a knowledge-intensive sector", Journal of Intellectual Capital, Vol. 10 No. 1, pp. $37-52$.

Cohen, S. and Kaimenaki, E. (2011), "Cost accounting systems structure and information quality properties: an empirical analysis", Journal of Applied Accounting Research, Vol. 12 No. 1 , pp. 5-25.

Cronbach, L.J. (1951), "Coefficient alpha and the internal structure of tests", Psychometrika, Vol. 16 No. 3, pp. 297-334.

Davila, A., Foster, G. and Oyon, D. (2009), “Accounting and control, entrepreneurship and innovation: Venturing into new research opportunities", European Accounting Review, Vol. 18 No. 2, pp. 281-311.

Ern, S.Y., Abdullah, A. and Yau, F.S. (2016), "Contingency Factors Influencing MAS Design of Manufacturing Firms in Malaysia", Asian Journal of Accounting and Governance, Vol. 7, pp. 1-9. 
Etemadi, H., Dilami, Z.D., Bazaz, M.S. and Parameswaran, R. (2009), “Culture, management accounting and managerial performance: Focus Iran", Advances in Accounting, Elsevier Ltd, Vol. 25 No. 2, pp. 216-225.

Faherty, U. and Stephens, S. (2016), "Innovation in micro enterprises: reality or fiction?", Journal of Small Business and Enterprise Development, Vol. 23 No. 2, pp. 349-362.

Fong, S.C.C. and Quaddus, M. (2010), "Intranet use in Hong Kong public hospitals", International Journal of Accounting and Information Management, Vol. 18 No. 2, pp. $156-181$.

Fornell, C. and Larcker, D.F. (1981), "Evaluating SEM with unobservable variables and measurement error", Journal of Marketing Research, Vol. 18, pp. 39-50.

Frezatti, F., Aguiar, A.B., Guerreiro, R. and Gouvea, M.A. (2011), “Does management accounting play role in planning process?", Journal of Business Research, Elsevier Inc., Vol. 64 No. 3, pp. 242-249.

Ghasemi, R., Azmi Mohamad, N., Karami, M., Hafiz Bajuri, N. and Asgharizade, E. (2016), "The mediating effect of management accounting system on the relationship between competition and managerial performance", International Journal of Accounting \& Information Management, Vol. 24 No. 3, pp. 272-295.

Ghasemi, R., Habibi, H.R., Ghasemlo, M. and Karami, M. (2019), "The effectiveness of management accounting systems: evidence from financial organizations in Iran", Journal of Accounting in Emerging Economies, Vol. 9 No. 2, pp. 182-207.

Gunarathne, A.D.N. and Lee, K.-H. (2019), "Environmental and managerial information for cleaner production strategies: An environmental management development perspective", Journal of Cleaner Production, Elsevier Ltd, Vol. 237, p. 117849.

Hair, J.F., Black, W.C., Babin, B.J. and Anderson, R.E. (2014), Multivariate Data Analysis, Pearson Education Limited, Seventh ed.

Hall, M. (2008), "The effect of comprehensive performance measurement systems on role clarity, psychological empowerment and managerial performance", Accounting, Organizations and Society, Vol. 33 No. 2-3, pp. 141-163. 
Hammad, S.A., Jusoh, R. and Ghozali, I. (2013), "Decentralization, perceived environmental uncertainty, managerial performance and management accounting system information in Egyptian hospitals", International Journal of Accounting and Information Management, Vol. 21 No. 4, pp. 314-330.

Hariyati, H., Tjahjadi, B. and Soewarno, N. (2019), "The mediating effect of intellectual capital, management accounting information systems, internal process performance, and customer performance", International Journal of Productivity and Performance Management, pp. 1250-1271.

Harrison, J.L. (2009), "Untangling the value of information scope: An investigation in retail pharmacies", Journal of Management and Organization, Vol. 15 No. 4, pp. 470-485.

Heidmann, M., Schäffer, U. and Strahringer, S. (2008), "Exploring the Role of Management Accounting Systems in Strategic Sensemaking", Information Systems Management, Vol. 25 No. 3, pp. 244-257.

Hoque, Z. (2011), "The relations among competition, delegation, management accounting systems change and performance: A path model", Advances in Accounting, Elsevier Ltd, Vol. 27 No. 2, pp. 266-277.

Hoyle, R.H. (1995), "The structural equation modeling approach: basic concepts and fundamental issues", in Sage Publications, I. (Ed.),Structural Equation Modeling: Concepts, Issues, and Applications, Thousand Oaks, CA, R.H. Hoyle., pp. 1-15.

Ismail, K., Isa, C.R. and Mia, L. (2018), “Evidence on the usefulness of management accounting systems in integrated manufacturing environment", Pacific Accounting Review, Vol. 30 No. 1, pp. 2-19.

Ismail, T., Meutia, M. and Ummi, N. (2019), "Enabling management control in improving the performance of SMEs", Management Science Letters, Vol. 9 No. 11, pp. 1823-1832.

Ivankovič, G., Janković, S. and Peršić, S. (2010), “Framework for performance measurement in hospitality industry-case study Slovenia", Economic Research - Ekonomska Istrazivanja, Vol. 23 No. 3, pp. 12-23.

Kline, R.B. (2011), Principles of structural equation modeling, The Gluiford Press, New York, 
3rded.

Koufteros, X., Babbar, S. and Kaighobadi, M. (2009), "A paradigm for examining second-order factor models employing structural equation modeling", International Journal of Production Economics, Elsevier, Vol. 120 No. 2, pp. 633-652.

Lavia López, O. and Hiebl, M.R.W. (2015), “Management Accounting in Small and MediumSized Enterprises: Current Knowledge and Avenues for Further Research", Journal of Management Accounting Research, Vol. 27 No. 1, pp. 81-119.

Linn, G., Casey, K.M., Johnson, G.H. and Ellis, T.S. (2001), "Do broad scope managerial accounting systems moderate the effects of budget emphasis, budget participation and perceived environmental uncertainty on the propensity to create budgetary slack?", Journal of Computer Information Systems, Vol. 42 No. 1, pp. 90-96.

Macinati, M.S. and Anessi-Pessina, E. (2014), "Management accounting use and financial performance in public health-care organisations: Evidence from the Italian National Health Service", Health Policy, Elsevier Ireland Ltd, doi:10.1016/j.healthpol.2014.03.011.

Mahoney, T.A., Jerdee, T.H. and Caroll, S.J. (1963), Development of managerial performance: a research approach, South-Western, Cincinnati, $\mathrm{OH}$.

Malmi, T. and Brown, D.A. (2008), "Management control systems as a package - Opportunities, challenges and research directions", Management Accounting Research, Vol. 19 No. 4, pp. 287-300.

Malmi, T. and Granlund, M. (2009), "In Search of Management Accounting Theory", European Accounting Review, Vol. 18 No. 3, pp. 597-620.

Mia, L. and Patiar, A. (2001), "The use of management accounting systems in hotels: an exploratory study", International Journal of Hospitality Management, Vol. 20 No. 2, pp. $111-128$.

Mollanazari, M. and Abdolkarimi, E. (2012), "The Effects of Task, Organization and Accounting Information Systems Characteristics on the Accounting Information Systems Performance in Tehran Stock Exchange", International Journal of Innovation, Management and Technology, Vol. 3 No. 4, pp. 443-448. 
Moores, K. and Yuen, S. (2001), “Management accounting systems and organizational configuration: A life-cycle perspective", Accounting, Organizations and Society, Vol. 26 No. 4-5, pp. 351-389.

Naranjo-Gil, D. (2009), “Management information systems and strategic performances: The role of top team composition", International Journal of Information Management, Vol. 29 No. 2, pp. 104-110.

Naranjo-Gil, D. and Hartmann, F. (2007), “Management accounting systems, top management team heterogeneity and strategic change", Accounting, Organizations and Society, Vol. 32 No. 7-8, pp. 735-756.

Novas, J.C., Alves, M. do C.G. and Sousa, A. (2017), "The role of management accounting systems in the development of intellectual capital", Journal of Intellectual Capital, Vol. 18 No. 2, pp. 286-315.

Pavlatos, O. and Paggios, I. (2009), "Management accounting practices in the Greek hospitality industry", Managerial Auditing Journal, Vol. 24 No. 1, pp. 81-98.

Pelz, M. (2019), “Can Management Accounting Be Helpful for Young and Small Companies? Systematic Review of a Paradox", International Journal of Management Reviews, Vol. 21 No. 2, pp. 256-274.

Perego, P. and Hartmann, F. (2009), “Aligning performance measurement systems with strategy: The case of environmental strategy", Abacus, Vol. 45 No. 4, pp. 397-428.

Pondeville, S., Swaen, V. and De Rongé, Y. (2013), "Environmental management control systems: The role of contextual and strategic factors", Management Accounting Research, Elsevier Ltd, Vol. 24 No. 4, pp. 317-332.

Ramli, I. and Iskandar, D. (2014), "Control authority, business strategy, and the characteristics of management accounting information systems", Procedia - Social and Behavioral Sciences, Elsevier B.V., Vol. 164 No. August, pp. 384-390.

Sandalgaard, N. and Nielsen, C. (2018), "Budget emphasis in small and medium-sized enterprises: evidence from Denmark", Journal of Applied Accounting Research, Vol. 19 No. 3, pp. 351-364. 
Sharma, R., Jones, S. and Ratnatunga, J. (2006), "The relationships among broad scope MAS, managerial control, performance, and job relevant information: A concomitant analysis", Review of Accounting and Finance, Vol. 5 No. 3, pp. 228-250.

Soobaroyen, T. and Poorundersing, B. (2008), "The effectiveness of management accounting systems: Evidence from functional managers in a developing country", Managerial Auditing Journal, Vol. 23 No. 2, pp. 187-219.

Tabachnick, B.G. and Fidell, L.S. (2007), Using Multivariate Statistics, Allyn and Bacon, New York, 5thed.

Velez, M.L., Sanchez, J.M., Florez, R. and Alvarez-Dardet, C. (2015), “How control system information characteristics affect exporter-intermediary relationship quality", International Business Review, Elsevier Ltd, Vol. 24 No. 5, pp. 812-824.

Williams, J.J. and Seaman, A.E. (2002), "Management accounting systems change and departmental performance: The influence of managerial information and task uncertainty", Vol. 13 No. 4, pp. 419-445.

Zimmerman, J.L. (2001), “Conjectures regarding empirical managerial accounting research", Journal of Accounting and Economics, Vol. 32 No. 1-3, pp. 411-427. 


\section{Appendix A - Dimensions of information characteristics provided by MAS}

\begin{tabular}{|c|c|c|c|c|c|c|}
\hline Code & Variables & Mean & S.E. & S.D. & Skew. & Kurt. \\
\hline SCO01 & Information which relates to possible future events (e.g. new projects) & 4.40 & 0.087 & 1.47 & 0.110 & -0.675 \\
\hline SCO02 & $\begin{array}{l}\text { Quantification of the likelihood of futures events occurring (e.g., } \\
\text { probability estimates) }\end{array}$ & 4.41 & 0.089 & 1.50 & 0.047 & -0.816 \\
\hline SCO03 & $\begin{array}{l}\text { Non-economic information (e.g., customer preferences, employee } \\
\text { attitudes, labor relations, attitudes of government and consumer } \\
\text { bodies, competitive threats, etc.) }\end{array}$ & 3.76 & 0.089 & 1.50 & 0.349 & -0.462 \\
\hline SCO04* & $\begin{array}{l}\text { Information on broad factors external to your organization (e.g. } \\
\text { economic conditions, population growth, technological developments, } \\
\text { etc.) }\end{array}$ & 4.02 & 0.086 & 1.46 & 0.199 & -0.402 \\
\hline SCO05* & $\begin{array}{l}\text { Non-financial information that relates to production and market area, } \\
\text { such as productivity, employee absenteeism, market size, growth } \\
\text { share, etc. }\end{array}$ & 4.33 & 0.089 & 1.50 & 0.110 & -0.699 \\
\hline TIM01 & Requested information to arrive immediately upon request & 4.68 & 0.083 & 1.39 & 0.034 & -0.522 \\
\hline TIM02* & $\begin{array}{l}\text { Information supplied to you automatically upon its receipt into } \\
\text { information systems or as soon as processing is completed }\end{array}$ & 4.84 & 0.082 & 1.38 & -0.081 & -0.383 \\
\hline TIM03 & $\begin{array}{l}\text { Reports are provided frequently on a systematic, regular basis (e.g., } \\
\text { daily reports, weekly reports) }\end{array}$ & 5.12 & 0.086 & 1.46 & -0.175 & -1.043 \\
\hline TIM04 & $\begin{array}{l}\text { There is no delay between an event occurring and relevant } \\
\text { information being reported to you }\end{array}$ & 4.53 & 0.085 & 1.43 & 0.012 & -0.761 \\
\hline AGG01 & $\begin{array}{l}\text { Information provided on the different sections or functional areas in } \\
\text { your organization (e.g. marketing and production, or sales, cost, or } \\
\text { profit centers) }\end{array}$ & 4.81 & 0.087 & 1.47 & -0.182 & -0.706 \\
\hline AGG02 & $\begin{array}{l}\text { Information on the effect of events on particular time periods (e.g., } \\
\text { monthly / quarterly / annual summaries, trends, comparisons, etc.) }\end{array}$ & 4.72 & 0.082 & 1.38 & -0.080 & -0.593 \\
\hline AGG03 & $\begin{array}{l}\text { Information which has been processed to show the influence of } \\
\text { events on different functions (e.g., marketing or production associated } \\
\text { with particular activities or tasks) }\end{array}$ & 4.10 & 0.084 & 1.41 & 0.164 & -0.447 \\
\hline AGG04 & $\begin{array}{l}\text { Information on the effect of different sections' activities on summary } \\
\text { reports (e.g., profit, cost, revenue reports) for your particular sections } \\
\text { and for the overall organization }\end{array}$ & 4.45 & 0.085 & 1.43 & 0.056 & -0.683 \\
\hline AGG05* & $\begin{array}{l}\text { Information in forms which enable you to conduct "what if" analysis } \\
\text { (e.g., sensitive analysis, scenario analysis) }\end{array}$ & 3.90 & 0.092 & 1.54 & 0.206 & -0.676 \\
\hline AGG06 & $\begin{array}{l}\text { Information in formats suitable for input into decision models (e.g., } \\
\text { discounted cash flow analysis, incremental or marginal analysis, } \\
\text { inventory analysis, credit policy analysis, etc.) }\end{array}$ & 4.47 & 0.094 & 1.59 & 0.025 & -0.881 \\
\hline AGG07* & Costs separated into fixed and variable components & 5.07 & 0.091 & 1.54 & -0.431 & -0.627 \\
\hline INT01 & $\begin{array}{l}\text { Information on the impact that your decision will have throughout } \\
\text { your department, and the influence of other individuals' decisions on } \\
\text { your area of responsibility }\end{array}$ & 4.48 & 0.093 & 1.57 & -0.039 & -0.862 \\
\hline INT02 & Precise targets for the activities of all sections within your department & 4.93 & 0.091 & 1.54 & -0.462 & -0.443 \\
\hline INT03 & $\begin{array}{l}\text { Information that relates to the impact that your decisions have on the } \\
\text { performance of your department }\end{array}$ & 4.99 & 0.085 & 1.43 & -0.364 & -0.572 \\
\hline
\end{tabular}

Notes: SE - Standard error; SD - Standard Deviation; Skew - Skewness; Kurt - Kurtosis; ${ }^{*}$ - Items dropped during the measurement model estimation process. 


\section{Appendix B - Construct used for measuring the managerial performance}

\begin{tabular}{|c|c|c|c|c|c|c|}
\hline Code & Variables & Mean & S.E. & S.D. & Skew. & Kurt \\
\hline MAP01 & $\begin{array}{l}\text { Planning: determining goals, policies, and courses of action (e.g., work } \\
\text { scheduling, budgeting, and programming) }\end{array}$ & 5.20 & 0.063 & 1.00 & -0.152 & 0.087 \\
\hline MAP02 & $\begin{array}{l}\text { Investigating: collecting and preparing information usually in the form } \\
\text { of records, reports, and accounts (e.g., measuring output, record } \\
\text { keeping, and job analysis) }\end{array}$ & 5.42 & 0.063 & 1.00 & -0.164 & -0.255 \\
\hline MAP03 & $\begin{array}{l}\text { Coordinating: exchanging information with people in the organization } \\
\text { other than my subordinates in order to relate and adjust procedures, } \\
\text { policies, and programs }\end{array}$ & 5.30 & 0.065 & 1.04 & -0.326 & -0.034 \\
\hline MAP04 & $\begin{array}{l}\text { Evaluating: assessment and appraisal of proposals or } \\
\text { reported/observed performance (e.g., employee appraisals, judging } \\
\text { financial performance and product inspection) }\end{array}$ & 4.98 & 0.066 & 1.06 & -0.258 & 0.091 \\
\hline MAP05 & Supervising: directing, leading, and developing your subordinates & 5.24 & 0.063 & 1.00 & -0.233 & 0.265 \\
\hline MAP06 & $\begin{array}{l}\text { Staffing: maintaining the workforce of your responsibility area (e.g., } \\
\text { selecting and promoting your subordinates) }\end{array}$ & 5.09 & 0.065 & 1.03 & -0.147 & 0.271 \\
\hline MAP07* & $\begin{array}{l}\text { Negotiating: purchasing, selling, or contracting for products or services } \\
\text { (e.g., contracting suppliers, collective bargaining) }\end{array}$ & 4.97 & 0.068 & 1.08 & -0.378 & 0.476 \\
\hline MAP08 & $\begin{array}{l}\text { Representing: Promote the general interests of the company } \\
\text { externally (e.g., participate in conventions, consultations with other } \\
\text { companies, groups or individuals, public speeches, interaction with } \\
\text { the community) }\end{array}$ & 4.81 & 0.079 & 1.26 & -0.412 & 0.193 \\
\hline MAP09 & $\begin{array}{l}\text { On overall, how would you rate your performance? ('not applicable' is } \\
\text { not an option) }\end{array}$ & 5.35 & 0.049 & 0.78 & -0.105 & -0.014 \\
\hline
\end{tabular}

Notes: SE - Standard error; SD - Standard deviation; Skew - Skewness; Kurt - Kurtosis; * - Items dropped during the measurement model estimation process. 
Figure 1: CFA results for second-order model

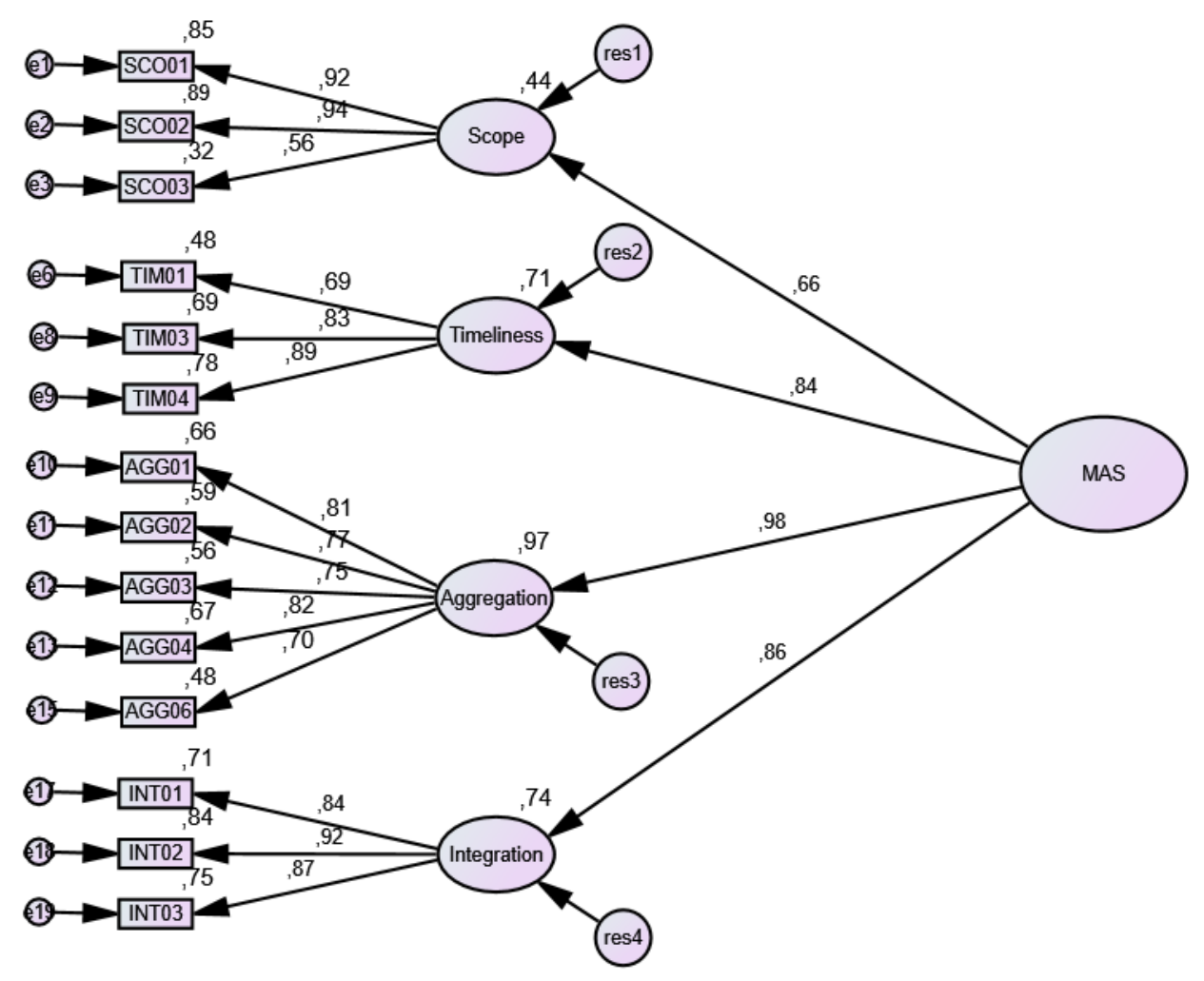


Figure 2: Structural model results

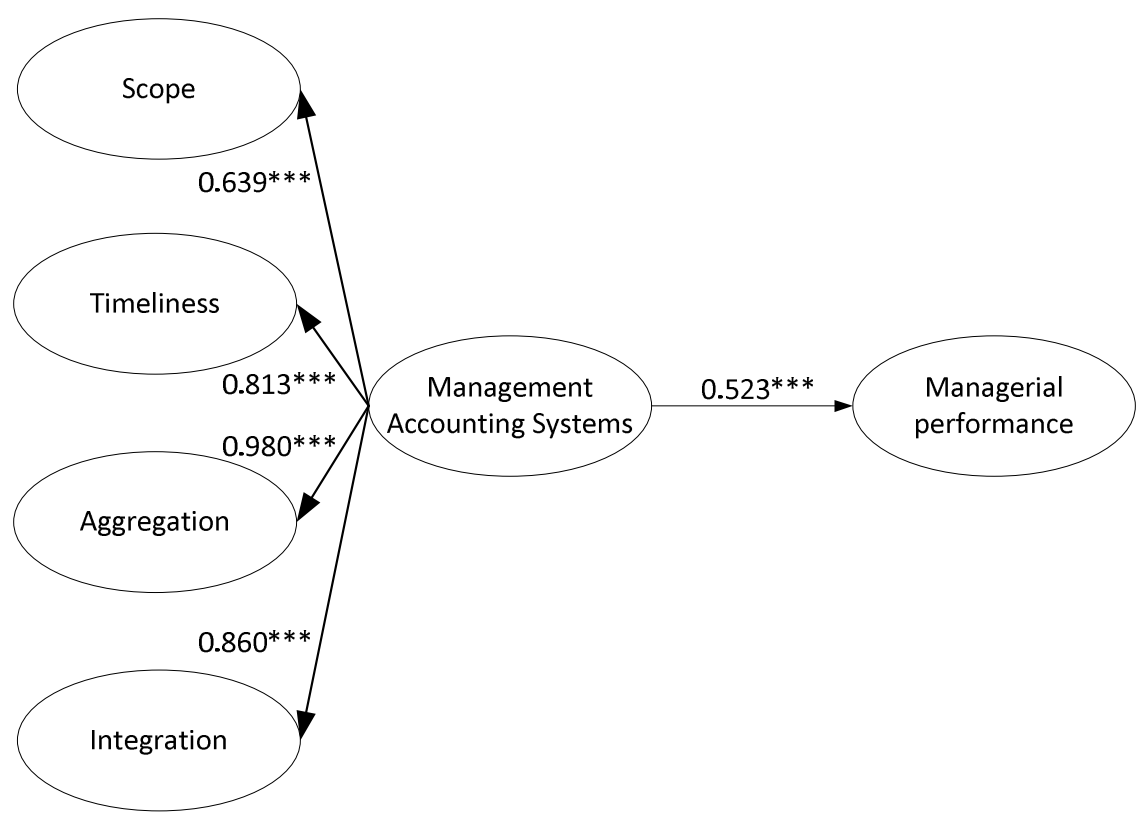


Table 1: MAS dimensions studied in previous articles

\begin{tabular}{|c|c|c|c|c|c|}
\hline Author(s) & Scope & Timeliness & Aggregation & Integration & $\begin{array}{c}\text { Dependent } \\
\text { variable }\end{array}$ \\
\hline Ghasemi et al. (2019) & s. & s. & s. & n.s. & MP \\
\hline Hariyati et al. (2019) & $\mathrm{m}$. & $\mathrm{m}$. & $\mathrm{m}$. & $\mathrm{m}$. & --- \\
\hline Gunarathne and Lee (2019) & m.r. & m.r. & m.r. & m.r. & $(2)$ \\
\hline Ismail, Isa, \& Mia (2018) & s. & s. & s. & s. & OP \\
\hline Ern, Abdullah, \& Yau (2016) & d. & d. & d. & d. & --- \\
\hline Ghasemi et al. (2016) & s. & s. & s. & n.s. & $\mathrm{MP}$ \\
\hline Velez et al. (2015) & s. & s. & n.s. & n.s. & (1) \\
\hline Ramli and Iskandar (2014) & d. & d. & d. & d. & --- \\
\hline Pondeville et al. (2013) & s. & - & - & - & (1) \\
\hline Hammad et al. (2013) & s. & s. & n.s. & n.s. & MP \\
\hline Mollanazari and Abdolkarimi (2012) & s. & s. & s. & - & (1) \\
\hline Frezatti et al. (2011) & m.r. & m.r. & m.r. & m.r. & $(2)$ \\
\hline Chiou (2011) & d. & d. & d. & - & --- \\
\hline Fong and Quaddus (2010) & d. & d. & d. & - & --- \\
\hline Perego and Hartmann (2009) & n.s. & n.s. & - & - & (1) \\
\hline Naranjo-Gil (2009) & s. & s. & s. & s. & SP \\
\hline Harrison (2009) & n.s. & - & - & - & OP \\
\hline Etemadi et al. (2009) & s. & s. & - & - & MP \\
\hline Heidmann et al. (2008) & m.r. & m.r. & - & - & (1) \\
\hline Soobaroyen and Poorundersing (2008) & s. & s. & s. & s. & MP \\
\hline Naranjo-Gil and Hartmann (2007) & s. & - & - & - & (1) \\
\hline Sharma et al. (2006) & s. & - & - & - & $\mathrm{MP}$ \\
\hline Agbejule (2005) & n.s. & n.s. & n.s. & n.s. & $\mathrm{MP}$ \\
\hline Chong (2004) & s. & - & - & - & MP \\
\hline Chang et al. (2003) & s. & s. & s. & - & $(1)$ \\
\hline Moores and Yuen (2001) & m.r. & m.r. & m.r. & m.r. & (2) \\
\hline Linn et al. (2001) & n.s. & - & - & - & (1) \\
\hline Bouwens and Abernethy (2000) & d. & d. & d. & d. & --- \\
\hline Chenhall and Morris (1986) & d. & d. & d. & d. & --- \\
\hline
\end{tabular}

MP - Managerial performance; OP - Organizational performance; SP - Strategic performance; (1) - Other organizational variables; (2) - non-relational model; s. - significant; n.s. - non significant; m.r. - mix results relating to different dependent variables; d. - MAS dimensions as dependent variables; m. - MAS as mediator variable. 
Table 2.a: Sample characteristics

\begin{tabular}{|c|c|c|}
\hline Item & Frequency & Percentage \\
\hline Turnover (M $€$ ) & \multirow[b]{2}{*}{0} & \multirow[b]{2}{*}{$0.00 \%$} \\
\hline Less than 2 & & \\
\hline From 2 to 10 & 7 & $2.46 \%$ \\
\hline From 10 to 20 & 139 & $48.94 \%$ \\
\hline From 20 to 35 & 60 & $21.13 \%$ \\
\hline From 35 to 50 & 17 & $5.99 \%$ \\
\hline More than 50 & 27 & $9.51 \%$ \\
\hline No response & 34 & $11.97 \%$ \\
\hline Total: & 284 & $100.00 \%$ \\
\hline Assets (M €) & \multirow[b]{2}{*}{1} & \multirow[b]{2}{*}{$0.35 \%$} \\
\hline Less than 2 & & \\
\hline From 2 to 5 & 28 & $9.86 \%$ \\
\hline From 5 to 10 & 47 & $16.55 \%$ \\
\hline From 10 to 20 & 71 & $25.00 \%$ \\
\hline From 20 to 30 & 45 & $15.85 \%$ \\
\hline From 30 to 43 & 20 & $7.04 \%$ \\
\hline More than 43 & 38 & $13.38 \%$ \\
\hline \multirow[t]{2}{*}{ No response } & 34 & $11.97 \%$ \\
\hline & 284 & $100.00 \%$ \\
\hline Number of employees & \multirow[b]{2}{*}{1} & \multirow[b]{2}{*}{$0.35 \%$} \\
\hline Less than 10 & & \\
\hline From 10 to 49 & 57 & $20.07 \%$ \\
\hline From 50 to 99 & 67 & $23.59 \%$ \\
\hline From 100 to 149 & 49 & $17.25 \%$ \\
\hline From 150 to 199 & 35 & $12.32 \%$ \\
\hline From 200 to 249 & 21 & $7.39 \%$ \\
\hline More than 250 & 20 & $7.04 \%$ \\
\hline \multirow[t]{2}{*}{ No response } & 34 & $11.97 \%$ \\
\hline & 284 & $100.00 \%$ \\
\hline
\end{tabular}


Table 2.b: Sample characteristics

\begin{tabular}{|c|c|c|}
\hline Industry & Frequency & Percentage \\
\hline $\begin{array}{l}\text { Wholesale trade and commission trade, except motor vehicles and } \\
\text { motorcycles }\end{array}$ & 45 & $15.85 \%$ \\
\hline Manufacture of food products and beverages & 30 & $10.56 \%$ \\
\hline $\begin{array}{l}\text { Sale, maintenance and repair of motor vehicles and motorcycles; retail } \\
\text { sale of automotive fuel }\end{array}$ & 20 & $7.04 \%$ \\
\hline Construction & 19 & $6.69 \%$ \\
\hline Manufacture of electrical machinery and apparatus n.e.c. & 14 & $4.93 \%$ \\
\hline $\begin{array}{l}\text { Manufacture of fabricated metal products, except machinery and } \\
\text { equipment }\end{array}$ & 11 & $3.87 \%$ \\
\hline Manufacture of other non-metallic mineral products & 9 & $3.17 \%$ \\
\hline Manufacture of machinery and equipment n.e.c. & 8 & $2.82 \%$ \\
\hline $\begin{array}{l}\text { Retail trade, except motor vehicles and motorcycles; repair of personal } \\
\text { and household goods }\end{array}$ & 8 & $2.82 \%$ \\
\hline Supporting and auxiliary transport activities; activities of travel agencies & 7 & $2.46 \%$ \\
\hline Manufacture of chemicals and chemical products & 6 & $2.11 \%$ \\
\hline Manufacture of rubber and plastics products & 6 & $2.11 \%$ \\
\hline Computer and related activities & 6 & $2.11 \%$ \\
\hline Manufacture of textiles & 5 & $1.76 \%$ \\
\hline Land transport; transport via pipelines & 5 & $1.76 \%$ \\
\hline Other business activities & 5 & $1.76 \%$ \\
\hline $\begin{array}{l}\text { Tanning and dressing of leather; manufacture of luggage, handbags, } \\
\text { saddlery, harness and footwear }\end{array}$ & 4 & $1.41 \%$ \\
\hline Manufacture of motor vehicles, trailers and semi-trailers & 4 & $1.41 \%$ \\
\hline Financial intermediation, except insurance and pension funding & 4 & $1.41 \%$ \\
\hline Miscellaneous (with less than three occurrences) & 37 & $13.03 \%$ \\
\hline \multirow[t]{2}{*}{ No response } & 31 & $10.92 \%$ \\
\hline & 284 & $100.00 \%$ \\
\hline
\end{tabular}


Table 3: Exploratory factor analysis results of MAS

\begin{tabular}{|c|c|c|c|c|c|}
\hline $\begin{array}{c}\text { Factors and } \\
\text { observed variables }\end{array}$ & $\begin{array}{l}\text { Loading } \\
\text { factor }\end{array}$ & $\alpha$ & $\begin{array}{l}\text { Item-total } \\
\text { correlation }\end{array}$ & KMO & $\begin{array}{l}\text { Bartlett's test } \\
\text { significance }\end{array}$ \\
\hline Scope & & 0.878 & & 0.760 & 0.000 \\
\hline SCO01 & 0.843 & & 0.738 & & \\
\hline SCO02 & 0.832 & & 0.722 & & \\
\hline SCO03 & 0.819 & & 0.709 & & \\
\hline SCO04 & 0.824 & & 0.717 & & \\
\hline SCO05 & 0.780 & & 0.659 & & \\
\hline Timeliness & & 0.885 & & 0.763 & 0.000 \\
\hline TIM01 & 0.853 & & 0.731 & & \\
\hline TIM02 & 0.880 & & 0.774 & & \\
\hline TIM03 & 0.866 & & 0.756 & & \\
\hline TIM04 & 0.850 & & 0.734 & & \\
\hline Aggregation & & 0.906 & & 0.890 & 0.000 \\
\hline AGG01 & 0.820 & & 0.742 & & \\
\hline AGG02 & 0.809 & & 0.728 & & \\
\hline AGG03 & 0.797 & & 0.709 & & \\
\hline AGG04 & 0.848 & & 0.777 & & \\
\hline AGG05 & 0.805 & & 0.726 & & \\
\hline AGG06 & 0.758 & & 0.675 & & \\
\hline AGG07 & 0.777 & & 0.695 & & \\
\hline Integration & & 0.906 & & 0.745 & 0.000 \\
\hline INT01 & 0.903 & & 0.786 & & \\
\hline INTO2 & 0.935 & & 0.846 & & \\
\hline INT03 & 0.915 & & 0.807 & & \\
\hline
\end{tabular}

Notes: $\alpha$-Chronbach's Alpha

Table 4: Pearson's coefficient of correlations, factorial validity and reliability

\begin{tabular}{|lrrrrrrr|}
\hline & Scope & Timeliness & Aggregation & Integration & $\boldsymbol{\alpha}$ & CR & AVE \\
\hline Scope & 0.686 & & & & 0.839 & 0.862 & 0.686 \\
Timeliness & 0.365 & 0.650 & & & 0.842 & 0.846 & 0.650 \\
Aggregation & 0.406 & 0.682 & 0.593 & & 0.874 & 0.879 & 0.593 \\
Integration & 0.320 & 0.494 & 0.724 & 0.767 & 0.906 & 0.908 & 0.767 \\
\hline
\end{tabular}

Notes: In the diagonal is the AVE; below the diagonal are the square of the correlations between the constructs; $\alpha$-Chronbach's Alpha; CR - Composite Reliability; AVE - Average Variance Extracted 
Table 5: Internal consistency and convergent validity

\begin{tabular}{|lcr|}
\hline & CR & AVE \\
\hline Management Accounting Systems & 0.907 & 0.712 \\
Scope & 0.862 & 0.685 \\
Timeliness & 0.847 & 0.650 \\
Aggregation & 0.879 & 0.593 \\
Integration & 0.908 & 0.767 \\
\hline
\end{tabular}

Notes: CR - Composite Reliability; AVE - Average Variance Extracted

Table 6: Exploratory factor analysis results of managerial performance

\begin{tabular}{|lccccc|}
\hline \multicolumn{1}{|c}{$\begin{array}{c}\text { Factors and observed } \\
\text { variables }\end{array}$} & $\begin{array}{c}\text { Loading } \\
\text { factor }\end{array}$ & $\alpha$ & $\begin{array}{c}\text { Item-total } \\
\text { correlation }\end{array}$ & KMO & $\begin{array}{c}\text { Bartlett's test } \\
\text { significance }\end{array}$ \\
\hline Managerial performance & & 0.923 & & 0.931 & 0.000 \\
M_P01 & 0.726 & & 0.798 & & \\
M_P02 & 0.630 & & 0.721 & & \\
M_P03 & 0.605 & & 0.710 & & \\
M_P04 & 0.719 & & 0.795 & & \\
M_P05 & 0.666 & & 0.751 & \\
M_P06 & 0.706 & & 0.789 & & \\
M_P07 & 0.583 & & 0.708 & & \\
M_P08 & 0.487 & & 0.630 & & \\
M_P09 & 0.550 & & 0.668 & & \\
Notes: $\alpha-$ Chronbach's Alpha & & & \\
\end{tabular}


Table 7: Confirmatory factor analysis results

\begin{tabular}{|c|c|c|c|c|}
\hline Factors and observed variables & Loading factor & $\alpha$ & CR & AVE \\
\hline Management Accounting Systems & & & 0.898 & 0.692 \\
\hline Scope & 0.639 & 0.825 & 0.853 & 0.671 \\
\hline SCO01 & 0.931 & & & \\
\hline SCO02 & 0.926 & & & \\
\hline SCO03 & 0.536 & & & \\
\hline Timeliness & 0.813 & 0.825 & 0.833 & 0.628 \\
\hline TIM01 & 0.662 & & & \\
\hline TIM03 & 0.821 & & & \\
\hline TIM04 & 0.878 & & & \\
\hline Aggregation & 0.980 & 0.851 & 0.855 & 0.542 \\
\hline AGG01 & 0.774 & & & \\
\hline AGG02 & 0.716 & & & \\
\hline AGG03 & 0.712 & & & \\
\hline AGG04 & 0.790 & & & \\
\hline AGG06 & 0.685 & & & \\
\hline Integration & 0.860 & 0.896 & 0.899 & 0.747 \\
\hline INT01 & 0.817 & & & \\
\hline INT02 & 0.913 & & & \\
\hline INT03 & 0.861 & & & \\
\hline Managerial performance & & 0.915 & 0.920 & 0.593 \\
\hline M_P01 & 0.836 & & & \\
\hline M_P02 & 0.790 & & & \\
\hline M_P03 & 0.751 & & & \\
\hline M_P04 & 0.828 & & & \\
\hline M_P05 & 0.795 & & & \\
\hline M_P06 & 0.807 & & & \\
\hline M_P08 & 0.621 & & & \\
\hline M_P09 & 0.710 & & & \\
\hline
\end{tabular}

Notes: $\alpha$-Chronbach's Alpha; CR - Composite Reliability; AVE - Average Variance Extracted 